\title{
PENGEMBANGAN SISTEM INFORMASI AKADEMIK UNTUK PENDAFTARAN UJIAN SIDANG LAPORAN AKHIR MAHASISWA STIKes HANG TUAH PEKANBARU
}

\author{
Yulisman \\ STMIK Hang Tuah Pekanbaru \\ J1. Mustafa Sari No. 5 Tangkerang Selatan, Pekanbaru - Riau \\ e-mail :yulismanaziera27@gmail.com
}

\begin{abstract}
ABSTRAK
Perkembangan teknologi informasi dalam dunia pendidikan yang semakin meluas, terutama Pendidikan Tinggi (PT). Sekolah Tinggi Ilmu Kesehatan (STIKes) Hang Tuah Pekanbaru merupakan salah satu lembaga pendidikan tinggi yang menerapkan sistem informasi akademik dalam kegiatan akademik. Penerapan sistem informasi akademik berjalan lancar, meskipun masih ada kekurangan dari sistem informasi akademik, salah satunya belum tersedianya form dan reaport informasi pendaftaran ujian sidang laporan akhir seperti Karya Ilmiah Magister/Tesis, Skripsi, dan Karya Tulis Ilmiah bagi mahasiswa STIKes Hang Tuah Pekanbaru yang sedang menyusun laporan akhir, sehingga diperlukan pengembangan sistem informasi. Penelitian ini bertujuan meningkatkan pelayanan akademik kepada mahasiswa, efektivitas dokumentasi form pendaftaran ujian sidang laporan, serta menyediakan informasi data alumni secara lengkap. Metode penelitian yang digunakan adalah model Waterfall yang merupakan bagian pengembangan sistem SDLC (Systems Development Life Cycle). Bahasa pemrograman yang digunakan PHP dan MySQL sebagai basis data. Hasil penelitian dan pengembangan sistem informasi pendaftaran ujian sidang laporan akhir ini bisa meningkatkan pelayanan akademik kepada mahasiswa terutama dalam dokumentasi form pendaftaran lebih efektif dan informasi yang diperoleh terhadap data mahasiswa yang telah ujian sidang akhir lebih cepat dan akurat.
\end{abstract}

Kata kunci : Pengembangan Sistem, Informasi, Akademik, Laporan Akhir Mahasiswa

\begin{abstract}
The development of information technology in the world of education is increasingly widespread, especially Higher Education. Hang Tuah Pekanbaru College of Health Sciences is one of the higher education institutions that applies academic information systems in academic activities. The application of academic information systems runs smoothly, although there are still shortcomings of academic information systems, one of which is the unavailability of forms and reaport of registration information for final examination reports such as Masters/Thesis, Thesis, and Scientific Writing for students of STIKes Hang Tuah Pekanbaru is preparing a final report, so information system development is needed. This study aims to improve academic services to students, the effectiveness of the report trial exam registration form documentation, and provide complete alumni data information. The research method used is the Waterfall model which is part of the development of the SDLC (Systems Development Life Cycle) system. The programming language used by PHP and MySQL as a database. The results of the research and development of the registration information system of the final report trial examination can improve academic services to students, especially in the registration form documentation more effectively and the information obtained from data on students who have final trial exams is faster and more accurate.
\end{abstract}

Keywords : System Development, Information, Academic, Student Final Report

\section{PENDAHULUAN}

Perkembangan teknologi informasi telah banyak memberikan kontribusi besar bagi lembaga, instansi, atau perusahaan yang menerapkan dan mengandalkan teknologi informasi dalam menjalankan usahanya dalam 
I N F O R M A I I A

Jurnal Informatika, Manajemen dan Komputer, Vol. 11 No.1, Mei 2019

eISSN : 2580-3042

pISSN : 1979-0694

meningkatkan kegiatan pelayanan. Teknologi informasi menurut Haag \& Keen adalah seperangkat alat yang membantu pekerjaan dengan informasi serta melakukan tugas-tugas yang berhubungan dengan pemrosesan informasi (Kadir \& Triwahyuni, 2013). Teknologi informasi bisa dimanfaatkan untuk mampu bersaing dalam dunia pendidikan yang semakin meluas, terutama Pendidikan Tinggi (PT) baik Pendidikan Tinggi Negeri (PTN) maupun Pendidikan Tinggi Swasta (PTS) dituntut untuk mempersiapkan diri seoptimal mungkin yaitu dengan memaksimalkan kinerja bagian-bagian akademik untuk mampu berkompetensi mendukung sistem informasi yang unggul dengan mengedepankan efektifitas dan efisiensi dengan memaksimalkan sumber daya yang dimiliki oleh setiap lembaga pendidikan tinggi. Menurut Gelinas, Oram, dan Wiggins sistem informasi adalah suatu sistem buatan manusia yang secara umum terdiri atas sekumpulan komponen berbasis komputer dan manual yang dibuat untuk menghimpun, menyimpan, dan mengelola data serta menyediakan informasi keluaran kepada pemakai (Kadir, 2014).

Sistem Informasi Akademik merupakan salah satu sistem informasi yang bisa dimanfaatkan oleh lembaga pendidikan tinggi untuk meningkatkan pelayanan yang maksimal kepada mahasiswa dalam proses pengurusan administrasi akademik dan proses belajar dan mengajar. Sistem Informasi Akademik bisa dimanfaatkan mahasiswa dalam memperoleh informasi akademik, dari informasi jadwal perkuliahan, nilai, dosen pembimbing akademik hingga informasi-informasi lainnya yang mereka butuhkan dari awal perkuliahan dimulai hingga mereka wisuda nantinya. Sistem informasi Akademik dirancang khusus untuk memenuhi kebutuhan sebuah perguruan tinggi yang telah terkompterisasi untuk melakukan kegiatan akademik secara terstruktur, sehingga semua prosesnya dapat teratasi dengan cepat (Aditama, 2013).

Sekolah Tinggi Ilmu Kesehatan (STIKes) Hang Tuah Pekanbaru merupakan salah satu lembaga pendidikan tinggi swasta yang merupakan lembaga pendidikan tinggi yang memanfaatkan teknologi informasi. Pemanfaatan teknologi informasi terlihat dimana STIKes Hang Tuah Pekanbaru telah mempunyai dan menerapkan sistem informasi akademik dalam proses pelayanan akademik kepada mahasiswa. Penerapan sistem informasi akademik oleh STIKes Hang Tuah dalam kegiatan akademik berjalan lancar walaupun masih ada kekurangan dari sistem itu sendiri. Salah satu kekurangan dari

sistem informasi akademik STIKes Hang Tuah belum tersedianya form dan informasi pendaftaran ujian sidang laporan akhir (Karya Ilmiah Magister/Tesis, Skripsi, dan Karya Tulis Ilmiah) dan bagi mahasiswa yang sedang menyusun laporan akhir, sehingga diperlukan pengembangan sistem informasi. Menurut Avison dan Fitzgerald (2006), Galliers dan Land (2002) pengembangan sistem informasi didefinisikan sebagai proses penggalian gagasan, analisa, perancangan, dan penerapan (implementasi) suatu sistem informasi (Sarosa, 2017).

Pendaftaran ujian sidang akhir selama ini masing-masing program studi mewajibkan mahasiswa mengisi form pendaftaran ujian sidang laporan akhir (KIM/Tesis, Skripsi dan KTI/Tugas Akhir) secara tertulis sebagai salah satu syarat untuk ujian sidang. Pengisian form pendaftaran ini diisi setelah mahasiswa mendapatkan persetujuan dari dosen pembimbing untuk ujian sidang laporan akhir dengan menyerahkan lembar persetujuan yang telah ditanda tangan oleh dosen pembimbing kebagian panitia laporan akhir dimasing-masing prodi. Sebelum form pendaftaran diserahkan oleh mahasiswa kembali ke bagian panitia laporan akhir, mahasiswa diwajibkan melengkapi pesyaratan administrasi, seperti pas photo untuk ijazah dan copy kartu hasil studi, photo copy ijazah sekolah sebelumnya dan persyaratan lainnya. Setelah semua persyaratan terpenuhi, mahasiswa melakukan pendaftaran kebagian panitia sidang laporan akhir mahasiswa untuk mendapatkan waktu dan tempat ujian sidang akhir serta surat pengantar untuk dosen penguji ujian sidang laporan akhir mahasiswa. Namun pengisian form tersebut tidak efektif, karena banyak mahasiswa tidak mengisi form secara lengkap dan dari bukti di lapangan form tersebut tidak terdokumentasi dengan baik dan banyak yang hilang.

\section{METODOLOGI PENELITIAN}

Berdasarkan permasalahan yang dibahas pada penelitian ini adalah pengembangan sistem informasi, dimana metode yang cocok adalah metode pengembangan sistem SDLC (Systems Development Life Cycle) atau juga sering dikenal dengan sebutan siklus hidup sistem. Tahapantahapan dalam SDLC lebih mendukung setiap proses yang terjadi dalam pengembangan sistem. SDLC atau Software Development Life Cycle atau sering disebut juga System Development Life Cycle adalah proses mengembangkan atau mengubah suatu sistem perangkat lunak dengan menggunakan model-model dan metodologi yang 
I N F O R M A T I A

Jurnal Informatika, Manajemen dan Komputer, Vol. 11 No.1, Mei 2019

eISSN : 2580-3042

pISSN : 1979-0694

digunakan orang untuk mengembangkan sistemsistem perangkat lunak sebelumnya, berdasarkan best practice atau cara-cara yang sudah teruji baik (Sukamto \& Shalahuddin, 2013).

Model SDLC yang digunakan dalam penelitian ini adalah:

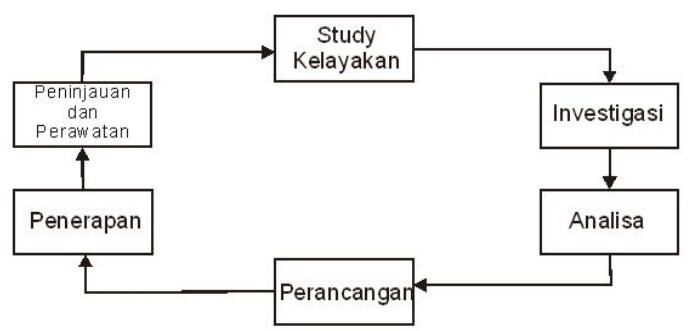

Gambar 1. Model Systems Development Life Cycle (SDLC)

Sumber : (Sarosa, 2017)

SDLC juga sering dikenal dengan istilah Waterfall karena pemodelan visual tahapan SDLC menyerupai air terjun. Model Waterfall ditunjukkan pada Gambar 2 berikut ini:

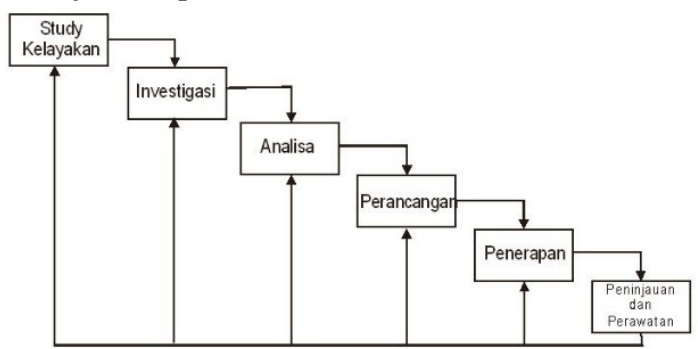

Gambar 2. Model SDLC dalam Bentuk Waterfall Sumber : (Sarosa, 2017)

Tahapan berikutnya adalah bagaimana proses pengembangan sistem informasi akademik ini berjalan lancar, tentunya peneliti harus mengikuti tahapan yang ada dalam SLDC itu sendiri, berikut kegiatannya:

a. Studi Kelayakan

Tahapan studi kelayakan peneliti melakukan analisa sistem mulai dari sistem yang sedang berjalan/manual yaitu peneliti langsung terlibat sebagai bagian salah dari panitia ujian sidang secara umum, dari analisa peneliti proses secara manual banyak kekurangan, terutama waktu proses sangat lama, penyimpanan dokumentasi terlalu menumpuk dan banyak yang hilang, serta proses manual lain yang tidak efektif. Selanjutnya, analisa proses Sistem Informasi Akademik yang telah berjalan dan peneliti dijadikan sebagai super user untuk bisa menganalisa sistem secara keseluruhan.

Hasil dari tahap studi kelayakan yang peneliti peroleh dan setelah di analisis, baik Sistem

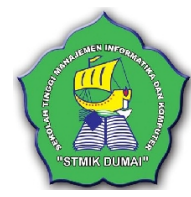

yang sedang berjalan/manual maupun Sistem Informasi Akademik yang telah berjalan bahwa untuk proses pendaftaran ujian sidang laporan akhir mahasiswa layak diterapkan dengan di Sistem Informasi Akademik dengan melakukan pengembangan sistem informasi pendaftaran ujian sidang laporan akhir (KIM/Tesis, Skripsi dan KTI/TA).

b. Investigasi

Ivestigasi merupakan tahapan dimana peneliti untuk melihat sacara langsung permasalahan sistem yang sedang berjalan, berikut tahapan penelitian yang dilakukan:

1. Penelitian Lapangan (Field Reseach)

Yaitu penelitian langsung ke STIKes Hang Tuah Pekanbaru sehingga penulis dapat mengetahui sistem informasi akademik yang dipakai dalam pengolahan data yang ada lembaga pendidikan tersebut. Penelitian lapangan dilakukan dengan dua cara :

a) Observasi (pengamatan langsung), di mana peneliti langsung berada dilokasi penelitian dan mengamati jalannya proses sistem baik manual maupun sistem informasi yang sudah jalan tersebut.

b) Wawancara, peneliti melakukan wawancara dengan panitia laporan akhir dan beberapa orang mahasiswa dimasing-masing dari program studi.

c) Sampling, yaitu teknik pengumpulan data yang dilakukan dengan cara melakukan pengambilan data arsip/formulir/catatan di STIKes Hang Tuah Pekanbaru.

2. Penelitian Pustaka (Library Reseach)

Dimana penulis dalam memperoleh bahan-bahan pokok permasalahan menggunakan buku-buku yang berhubungan dengan tema, topik dan permasalahan dalam penelitian.

3. Penelitian Labor (Laboratory Reseach) Penelitian yang lain juga dilakukan adalah penelitian dilaboratorium komputer dan ruang server dengan melakukan pengolahan data-data yang diperoleh.

c. Analisa

Tahap analisa ini peneliti mulai dari permasalahan yang ada pada pengisian form pendaftaran ujian sidang laporan akhir (KIM/Tesis, Skripsi dan KTI/Tugas Akhir) mahasiswa yang selama ini dilakukan secara tertulis tidak efektif dan masih bersifat konvesional, karena banyak mahasiswa tidak mengisi form secara lengkap dan juga tidak memenuhi semua pesyaratan administrasi 
ujian yang telah ditetapkan oleh prodi (panitia laporan akhir). Selanjutnya peneliti menganalisa Sistem Informasi Akademik Kampus (SIAK) yang sudah berjalan dan aktif. Berdasarkan analisa peneliti, solusi pengembangan sistem Sistem Informasi Akademik untuk pendaftaran ujian sidang laporan akhir mahasiswa dan untuk mengatasi permasalahan kehilangan dokumen dan data. Menumpuknya form pendaftaran ujian sidang laporan akhir berserta persyaratan lainnya disetiap tahunnya juga membutuhkan media penyimpanan yang banyak, oleh karena dibutuhkan pengembangan sistem informasi untuk meningkatkan pelayanan akademik yang prima kepada mahasiswa. Pengembangan sistem informasi akademik ini nantinya menggunakan metode SDLC (Systems Development Life Cycle), dalam proses pengembangan tersebut harus mengikuti tahapan dari metode SLDC itu sendiri.

d. Perancangan

Tahap perancangan ini peneliti mulai dari perancangan data masukan (input data) dan data keluaran (output data).

1. Data Masukan (Input Data)

Data masukan terdiri dari data mahasiswa yang sudah terdaftar di database dan aktif di semester yang sedang berjalan dan telah menyelesaikan Matakuliah wajib juga telah menyelesaikan jumlah maksimal SKS. Data jenis laporan akhir dan jenis penelitian, tanggal ujian proposal, tanggal persetujuan pembimbing, jumlah konsul, judul laporan akhir, nama kedua orang tua mahasiswa, nama suami/istri, data pekerjaan jika sudah bekerja, dosen pembimbing dan penguji KIM/Tesis, Skipsi dan KTI/Tugas Akhir, data instansi/perusahaan tempat penelitian dan data-data lain yang dibutuhkan dari mahasiswa dalam pengisian form ujian sidang laparan akhir.

2. Data Keluaran (Output Data)

Data keluaran yang dihasil oleh sistem berupa tabel yang menampilkan informasi data hasil pendaftaran ujian yang diinputkan melalui bisa form pendaftaran ujian sidang per mahasiswa. Data-data yang ada ditabel tersebut adalah data informasi laporan akhir mahasiswa dan jadwal ujian sidang.

e. Penerapan

Penerapan adalah tahapan sistem digabungkan dengan sistem informasi akademik yang lama. Penggabungan ini secara tidak langsung telah berlangsung ketika penambahan modul, dan modul langsung diuji. Tahap penerapan juga dilakukan penulisan coding program, kompilasi dan pengujian. Pengujian dilakukan dengan metode blackbox testing. Metode migrasi sistem yang digunakan migrasi modular, yaitu dengan langsung menjalankan modul pendaftaran ujian sidang mahasiswa ke sistem informasi akademik STIKes Hang Tuah Pekanbaru.

Selanjutnya konfigurasi penerapan sistem diperlukan satu unit komputer server, dua atau lebih komputer client, Local Area Network (LAN) dan untuk sistem operasi pada server bisa menggunakan windows server dan Linux Server serta perangkat lunak pendukungnya seperti aplikasi web server $M s$. IIS dan Apache.

Sistem operasi untuk komputer client bisa menggunakan windows xp, 7, 8, dan windows server, Linux Dekstop serta perangkat lunak pendukung untuk menjalankan sistem disarankan menggunakan web browser seperti Mozilla Firefox, Internet Explorer New Version (8.00), dan Google Croome.

f. Peninjauan Ulang dan Perawatan

Tahap peninjauan ulang dan perawatan ini dilakukan setelah sistem selesai dibangun dan penerapan dan berjalan sesuai harapan. Dalam operasional sistem tentu tidak selalu barjalan dengan baik, tentunya dengan perkembangan teknologi informasi sistem perlu dimodifikasi dan diperbaiki sesuai kebutuhkan. Secara reguler sistem harus ditinjau sesuai perubahan dan perkembangan lingkungan sistem dan bisnis organisasi. Perawatan sistem dijalankan terus-menerus, baik perawatan perangkat keras dan perangkat lunak sebagai pendukung sistem dan sampai nanti pada akhirnya sistem tersebut tidak mampu lagi memenuhi kebutuhan organisasi dan harus diganti dengan yang baru.

\section{HASIL DAN PEMBAHASAN}

Pengguna dari sistem informasi pendaftaran ujian sidang laporan akhir mahasiswa ini terdiri dari:

1. Mahasiswa

Mahasiswa sebagai pengguna (user) pertama dari sistem informasi pendaftaran ujian sidang. Mahasiswa untuk login ke sistem menggunakan NPM/NIM sebagai pengguna (user) serta tanggal lahir sebagai password 
I N F O R M A T IK A

Jurnal Informatika, Manajemen dan Komputer, Vol. 11 No.1, Mei 2019

eISSN : 2580-3042

pISSN : 1979-0694

default dari sistem atau password yang telah dirubah oleh mahasiswa yang bersangkutan.

2. Administrator

Administrator terdiri dari panitia laporan akhir mahasiswa dan staff BAAK adalah pengguna (user) kedua yang bisa login singkatan nama program studi dan bagian masing-masing administrator sebagai kode login dan 123456 sebagai password default dari sistem. Untuk merubah kode login dan password, administrator melakukan permohonan perubahan ke admin sistem.

3. Dosen

Sebagai dosen pembimbing dan penguji baik dosen tetap maupun tidak tetap adalah pengguna (user) ketiga yang juga bisa mengakses sistem termasuk sistem informasi pendaftaran ujian sidang, dimana dosen bisa login sebagai pengguna (user) menggunakan NIDN/NUPN sebagai kode login dan 123456 sebagai password default dari sistem dan sama dengan administrator, untuk merubah kode login dan password administrator melakukan permohonan perubahan ke admin sistem.

4. Pimpinan

Pimpinan merupakan pengguna (user) terakhir yang terdiri dari Ketua STIKes Hang Tuah Pekanbaru, Wakil Ketua I, II dan III serta Kepala Program Studi dari masingmasing program studi, Kepala BAAK dan Bagian-bagian yang berhubungan dengan informasi pendaftaran ujian sidang laporan akhir. Pimpinan bisa login ke sistem informasi akademik dengan kode login nama pimpinan atau nama jabatan pimpinan dan 123456 sebagai password default. Tujuan pimpinan sebagai pengguna (user) untuk mengetahui informasi mahasiswa yang melakukan pendaftaran ujian sidang dan data singkat tentang laporan akhir (KIM/Tesis, Skripsi, KTI/TA).

Tujuan dari perancangan sistem adalah untuk memberikan gambaran secara umum kepada user tentang sistem yang baru. Perancangan sistem merupakan persiapan dari percangan terinci yang disebut juga tahap pemecahan masalah yaitu dengan menyusun suatu alur sistem, prosedur sistem, masukan dan keluaran serta database. Sistem yang dibangun harus memperhatikan hasil analisis dan juga harus memperhatikan kebutuhan pemakai. Perancangan sistem ini sangat penting dilakukan dalam pembuatan sistem dari awal baik untuk sistem yang baru maupun pengembangan sistem.

Salah satu tahapan dari perancangan adalah Aliran Sistem Informasi (ASI) ini merupakan

bagian dari analisa aliran data atau dokumen dari dunia nyata yang disusun secara sistematis dengan menggunakan simbol-simbol.

Aliran Sistem Informasi (ASI) merupakan bagan yang menunjukan arus pekerjaan serta keseluruhan dari sistem. Bagan ini menjelaskan urutan dari prosedur-prosedur yang ada dalam system (Ismael, 2017).

1. Aliran Sistem Informasi (ASI) Lama

Berikut perancangan aliran sistem informasi lama di mana menjelaskan bagaimana sistem yang sedang berjalan saat ini dalam proses pengisian form pendaftaran ujian sidang laporan akhir.

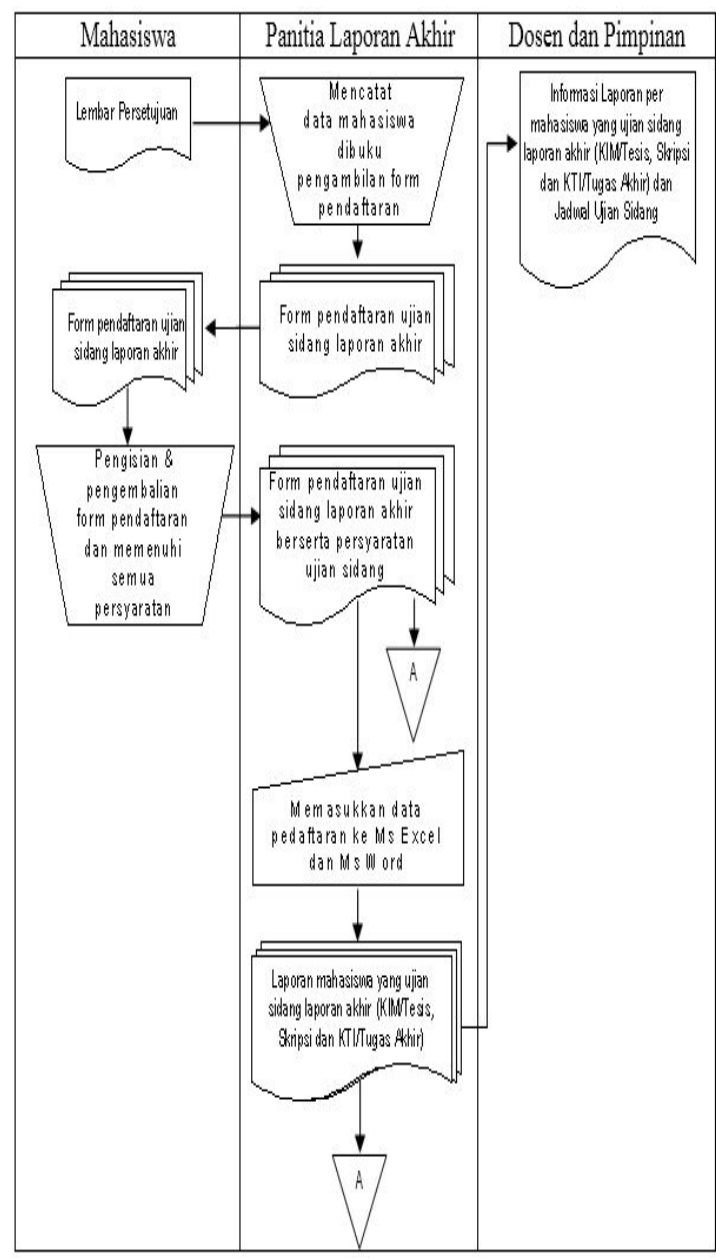

Gambar 3. Aliran Sistem Informasi (ASI) Lama

2. Aliran Sistem Informasi (ASI) Baru

Tahap berikutnya adalah perancangan Aliran Sistem Informasi (ASI) baru ini menjelaskan bagaimana proses sistem yang baru berjalan dengan mengoptimalisasikan peran sistem informasi akademik STIKes Hang Tuah Pekanbaru. 
I N F ORM A I K A

Jurnal Informatika, Manajemen dan Komputer, Vol. 11 No.1, Mei 2019

eISSN : 2580-3042

pISSN : 1979-0694

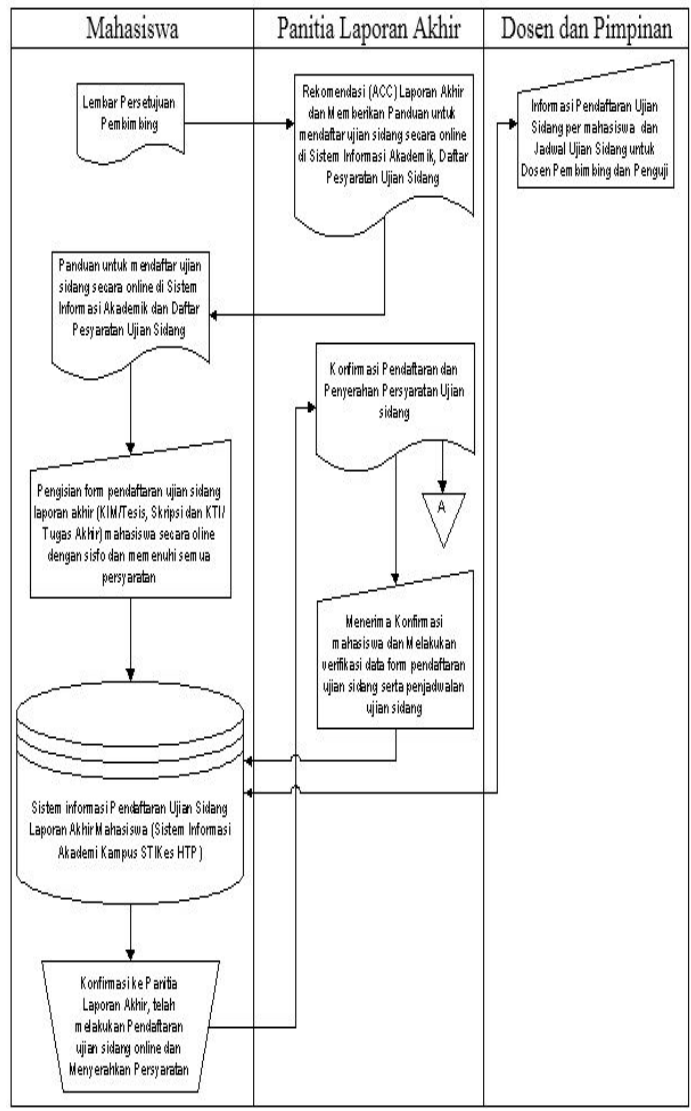

Gambar 4. Aliran Sistem Informasi (ASI) Baru

Proses pada gambar 4 diatas dapat dijelaskan secara singkat bahwa pendaftaran ujian sidang laporan akhir ini dimulai dari mahasiswa melapor ke bagian panitia laporan akhir di program studi masing-masing dengan membawa lembar persetujuan laporan akhir yang telah ditanda tangan oleh pembimbing. Selanjutnya panitia laporan akhir mengarahkan dan memberikan panduan untuk melakukan pendaftaran secara online di Sistem Informasi Akademik STIKes Hang Tuah Pekanbaru dengan login sebagai mahasiswa menggunakan NPM/NIM sebagai user serta tanggal lahir sebagai password default dari sistem atau password yang telah dirubah oleh mahasiswa yang bersangkutan. Secara otomotis mahasiswa telah terdaftar sesuai dengan program studi masing-masing.

Berdasarkan aliran sistem informasi (ASI) mahasiswa melakukan pendaftaran ke sistem informasi, apakah mahasiswa yang bersangkutan telah memenuhi persyaratan wajib yaitu telah mengambil matakuliah Karya Tulis Ilmiah/Tesis untuk mahasiswa pasca sarjana (S2), Skripsi

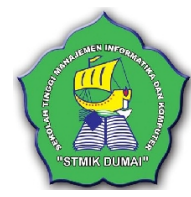

untuk mahasiswa Strata 1 (S1) dan Karya Tulis Ilmiah untuk mahasiswa Diploma Tiga (D-III) dan mengisi kartu rencana studi secara online di sistem informasi akademik. Jika mahasiswa. Jika mahasiswa yang bersangkutan tidak memenuhi persyaratan wajib diatas, maka mahasiswa tersebut belum bisa melakukan pendaftaran dan ujian sidang dan jika telah memenuhi persyaratan, mahasiswa tersebut bisa melakukan pendaftaran dan ujian sidang.

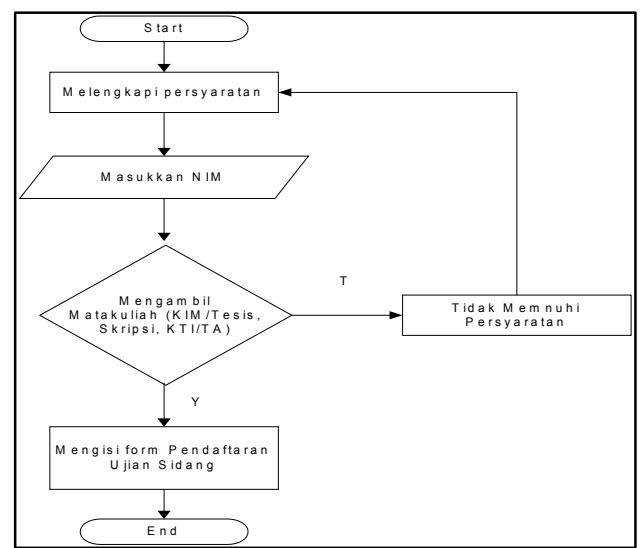

Gambar 5. Flowchart Pendaftaran Ujian Sidang Laporan Akhir Mahasiswa

3. Diagram Konteks (Context Diagram) Membuat diagram konteks, peneliti terlebih dahulu melakukan analisa data yang membutuhkan, dan selanjutnya ditentukan sumber data yang dibutuhkan sistem dan tujuan informasi yang dihasilkan sistem.

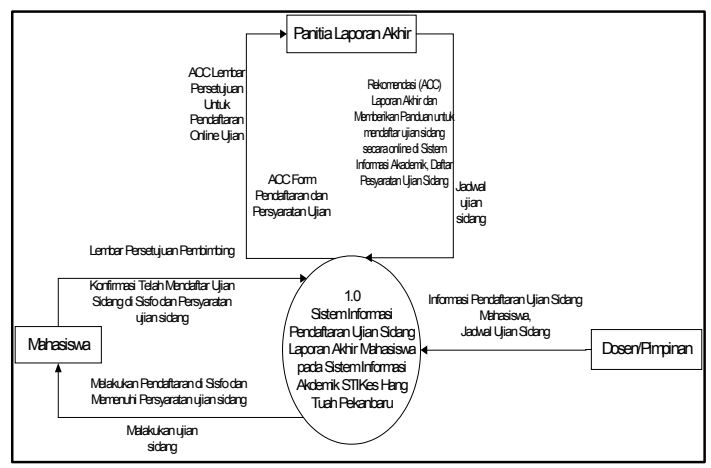

Gambar 5. Konteks Diagram (Diagram Context)

4. Data Flow Diagram (DFD)

Berikut dibawah ini gambaran DFD yang terdapat pada sistem informasi pendaftaran ujian sidang laporan akhir mahasiswa. 
I N F O R M A I I A

Jurnal Informatika, Manajemen dan Komputer, Vol. 11 No.1, Mei 2019

eISSN : 2580-3042

pISSN : 1979-0694

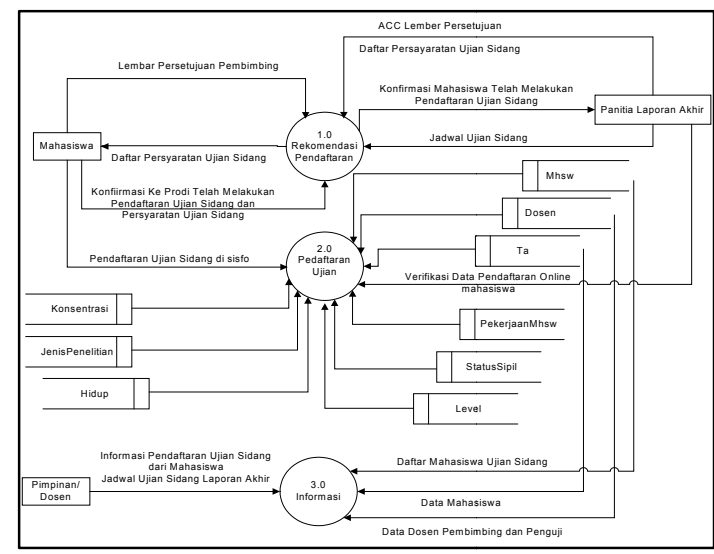

Gambar 6. Data Flow Diagram (DFD)

5. Perancangan Basis Data (Database)

Menurut Connolly Basis data merupakan tempat penyimpanan data yang besar dan tunggal yang dapat digunakan secara bersamaan oleh beberapa departemen atan pengguna (Agung, 2016). Basis data yang digunakan dalam pengembangan sistem informasi akademik pendaftaran ujian sidang ini adalah MySQL. MySQL (My Structure Query Language) adalah sebuah perangkat lunak sistem manajemen basis data SQL (Database Manajemen System) atau DBMS dari sekian banyak DBMS, seperti Oracle, MS SQL, Postagre SQL, dan lain-lain. $M y S Q L$ merupakan DBMS yang multithread, multi-user yang bersifat gratis atau open source sehingga kita bisa menggunakannya secara gratis dibawah lisensi GNU General Public Licence (GPL). Pemrograman PHP juga sangat mendukung/support dengan database MySQL sehingga apabila kita dapat mengaplikasikan $P H P$ \& $M y S Q L$ dalam membuat aplikasi website (Anhar, 2010).

Ada banyak cara untuk mengorganisasi skema, atau memodelkan struktur basis data ini yang dikenal sebagai model basis data atau model data salah satu model Entity Relationship Diagram (ERD). ERD dapat membantu dalam menjawab persoalan tentang data yang diperlukan dan bagaimana data tersebut saling berhubungan. Berikut perancangan ERD pada pengembangan sistem informasi pendaftaran ujian sidang laporan akhir mahasiswa:

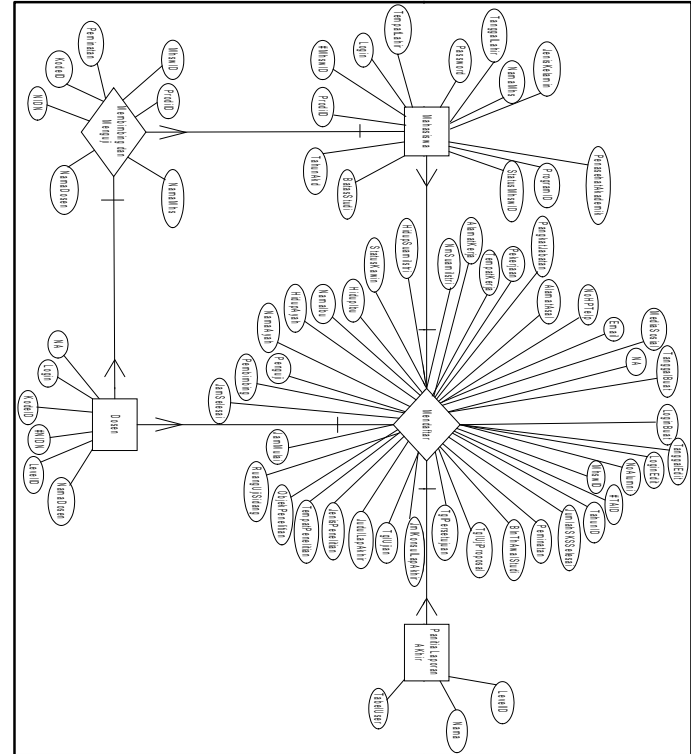

Gambar 7. ERD Pengembangan Sisfo

Pendaftaran Ujian Sidang Laporan Akhir Mahasiswa

Berikut tampilan input dan output dari pengembangan sistem informasi akademik pendaftaran ujian sidang laporan akhir mahasiswa:

a. Pembuatan Modul Pendaftaran Ujian Sidang Laporan Akhir (KIM/Tesis, Skripsi, KTI/TA) Mahasiswa

Pengembangan sistem informasi pendaftaran ujian sidang laporan akhir (KIM/Tesis, Skripsi, KTI/TA) mahasiswa ini dimulai dengan menambahkan sub modul Pendaftaran Ujian Sidang pada Group Modul Mahasiswa. Sebelum penambahan sub modul tersebut peneliti atau administrator, login sebagai superuser terlebih dahulu. Nama administrator sebagai kode login dan default password sebagai password. Berikut tampilan form login superuser:

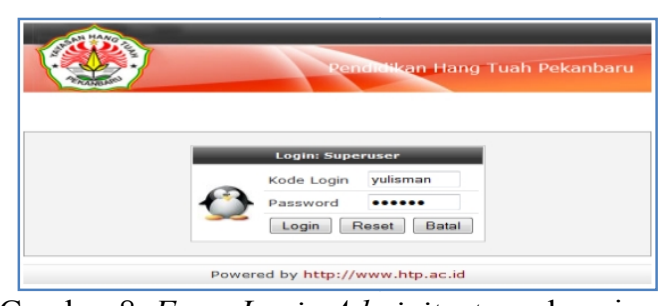

Gambar 8. Form Login Adminitrator sebagai Superuser

Setelah kode login dan password dimasukan klik login untuk masuk ke sistem informasi akademik akan tampil menu grup modul serta hak akses yang didapatkan oleh superuser, berikut tampilannya dibawah ini: 
I N F ORM A I K A

Jurnal Informatika, Manajemen dan Komputer, Vol. 11 No.1, Mei 2019

eISSN : 2580-3042

pISSN : 1979-0694

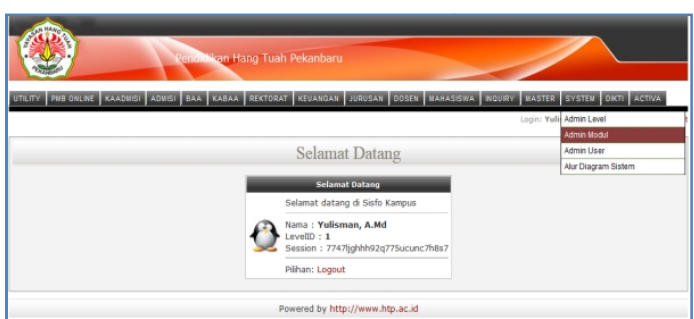

Gambar 9. Form Menu Utama Administrator sebagai Superuser

Setelah superuser masuk ke sistem dan memilih group modul system kemudian pilih admin modul dan akan tampil form modul sisfo kampus. Berikutnya untuk menambahkan sub modul pendaftaran ujian sidang pada gruop modul mahasiswa. Pilih group modul mahasiswa pada listbox gruop modul, dan klik tab tambah modul sehingga tampil form gruop modul mahasiswa, lalu klik tambah modul sehingga muncul tampilan form tambah sub modul, seperti gambar 2 berikut:

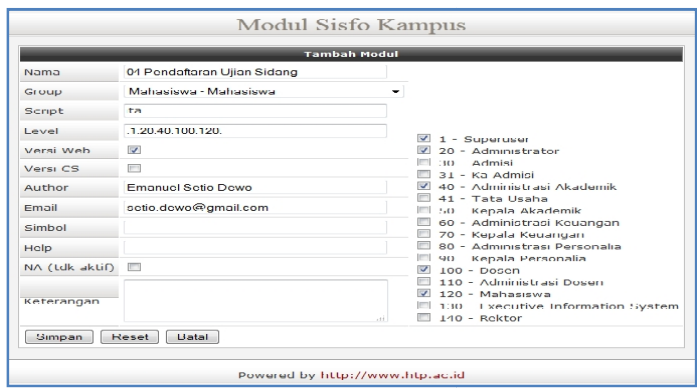

Gambar 10. Form Tambah Sub Modul

Selanjutnya form tambah modul tersebut diisi seperti yang terlihat pada gambar 3 dengan sub modul pendaftaran ujian sidang dengan memasukan nama sub modul, script dan level dari sub modul dengan menceklis daftar level user, selanjtnya klik simpan untuk menyimpan sub modul pendaftaran ujian siding dan hasilnya akan terlihat pada Gruop modul mahasiswa setelah ditambahkan sub modul pendaftaran ujian sidang seperti tampilan berikut:

\begin{tabular}{|l|}
\hline M A HASISW A \\
\hline 01 Kartu Rencana Studi (KRS) \\
\hline 02 Nilai Semester \\
\hline 03 data mahasiswa \\
\hline 04 Pendaftaran Ujian Sidang \\
\hline
\end{tabular}

Gambar 11. Tampilan Sub Modul Pendaftaran Ujian Sidang pada Group Mahasiswa

b. Pengoperasian dan Implementasi Sistem Informasi Pendaftaran Ujian Sidang Laporan

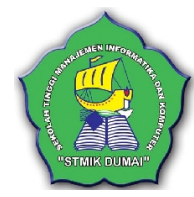

Akhir (KIM/Tesis, Skripsi, KTI/TA) Mahasiswa

1. Form Menu User pada Sistem Informasi Akademik

Form menu pengguna (user) adalah pilihan login user untuk masuk ke Sistem Informasi Akademik yang dirancang dengan 16 gruop user. Berikut tampilan form menu user:

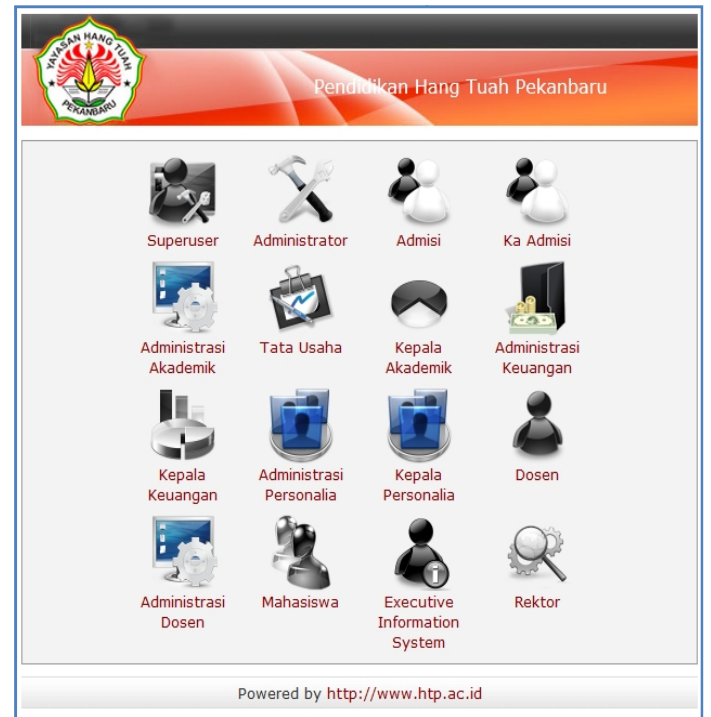

Gambar 12. Form Menu User pada Sistem Informasi Akademik

Dari form menu user di atas dapat dijelaskan bahwa pengguna (user) yang bisa masuk dan mengakses sistem informasi pendaftaran ujian sidang laporan akhir (KIM/Tesis, Skripsi, KTI/TA) mahasiswa hanya adminitrator, mahasiswa, dosen dan pimpinan yang terdiri Ketua Program Studi, Ka. BAAK, dan Ketua (Rektor).

2. Form Login Masing-masing Pengguna (User)

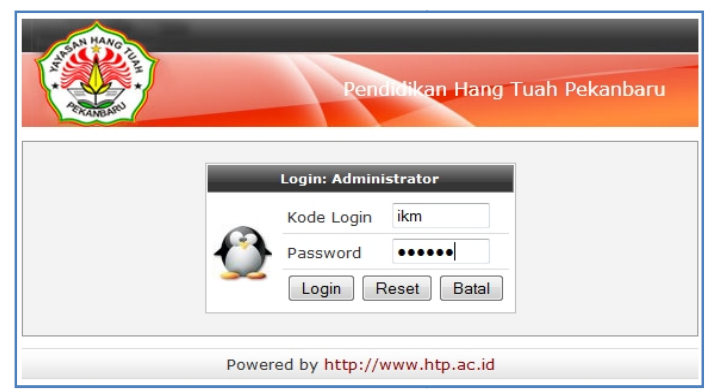

Gambar 13. Form Login Administrator 
I N F ORM A I K A

Jurnal Informatika, Manajemen dan Komputer, Vol. 11 No.1, Mei 2019

eISSN : 2580-3042

pISSN : 1979-0694

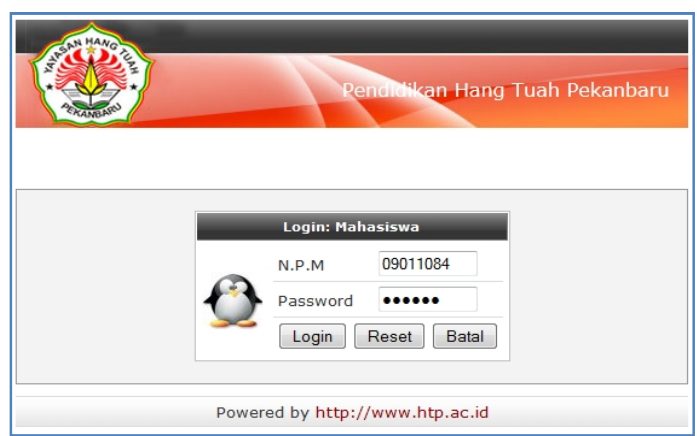

mengambil matakuliah $\mathrm{KIM} /$ Tesis untuk mahasiswa pasca sarjana (S2), skripsi untuk mahasiswa S1 dan KTI/TA untuk mahasiswa Diploma Tiga (D-III) yaitu dengan memasukan NIM mahasiswa untuk diproses apakah telah mengambil matakuliah tersebut diatas. Berikut tampilan form verifikasi persyaratan;

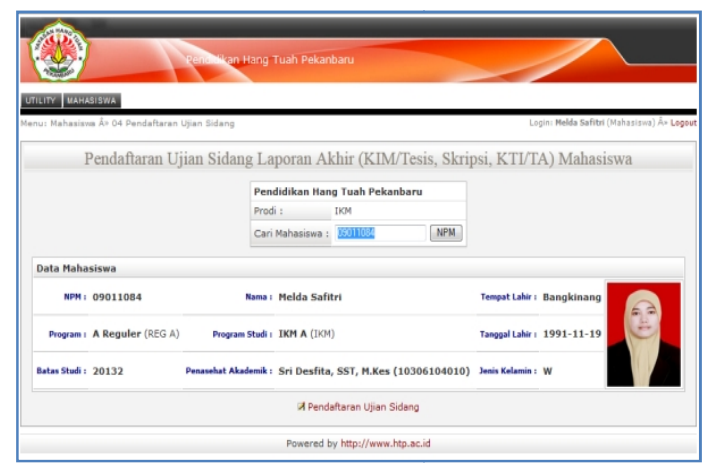

Gambar 18. Form Mahasiswa untuk

Verifikasi Persyaratan Pendaftaran Ujian Sidang

Gambar 15. Form Login Dosen

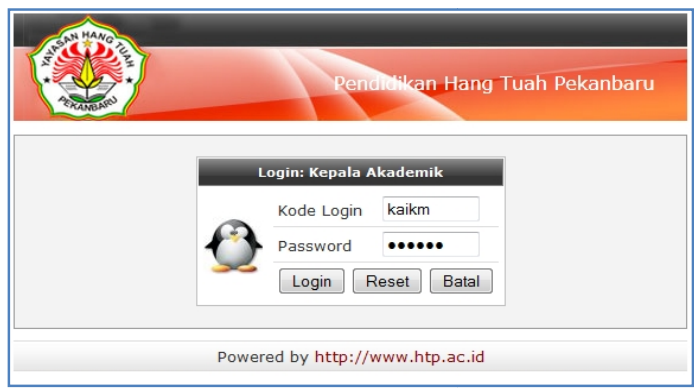

Gambar 16. Form Login Salah Satu Pimpinan

3. Pengisian Form Pendaftaran Ujian Sidang Oleh Mahasiswa

Sebelum mengisi form pendaftaran ujian

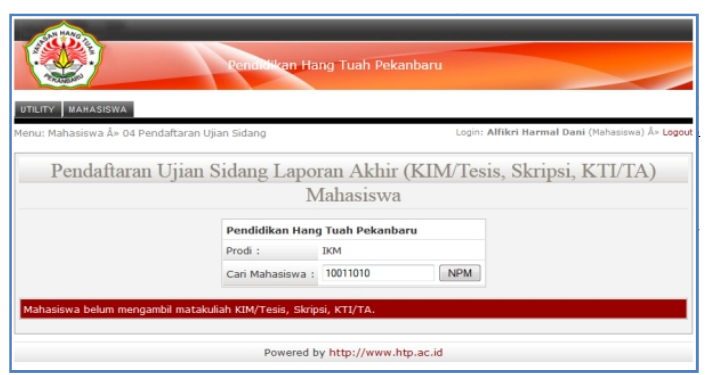

Gambar 17. Form Menu Utama Mahasiswa

Selanjutnya mahasiswa klik menu mahasiswa dan memilih sub menu Pendaftaran Ujian Sidang, dan tampil form (Gambar 11). Setelah mahasiswa memilih sub group modul pendaftaran ujian sidang akan tampil form verifikasi persyaratan dan pengisian form pendaftaran ujian sidang telah 
I N F ORM A I K A

Jurnal Informatika, Manajemen dan Komputer, Vol. 11 No.1, Mei 2019

eISSN : 2580-3042

pISSN : 1979-0694

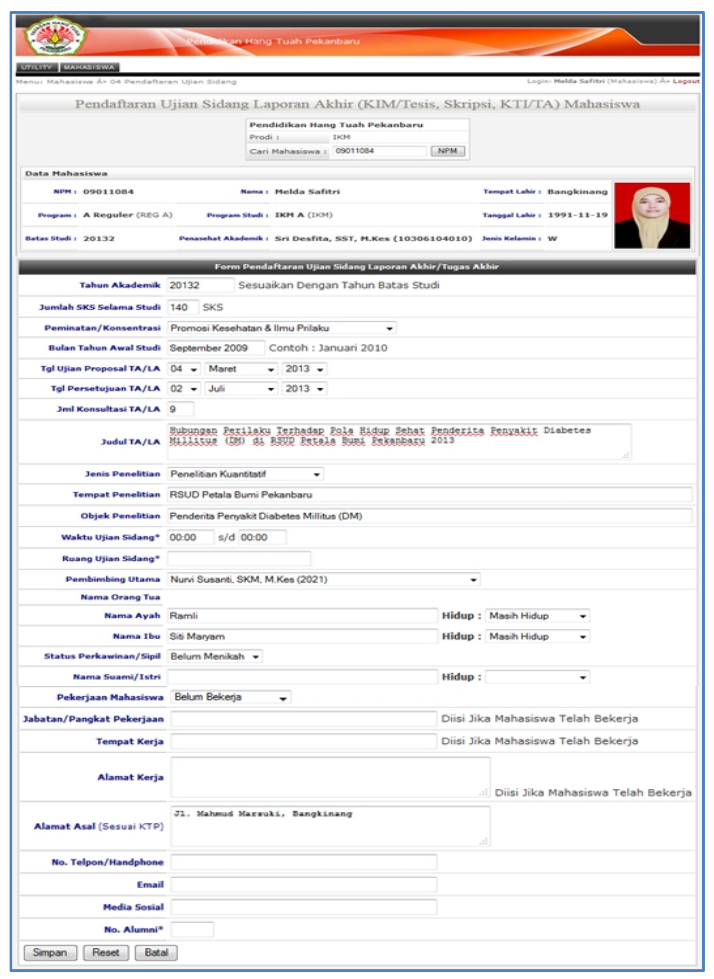

Gambar 20. Form Pengisian Form Pendaftaran Ujian Sidang

Setelah mahasiswa mengisi form pendaftaran ujian sidang secara lengkap selanjutnya klik tombol simpan untuk menyimpan data dan melihat tabel informasi pendaftaran ujian sidang. Selanjutnya mahasiswa menginputkan Dosen Penguji II terlebih dahulu dengan mengklik tombol edit dosen penguji pada kolom penguji. Setelah memilih dosen penguji pada listbox tambah dosen penguji klik tombol tambahkan dosen berikut tampilan form-nya:

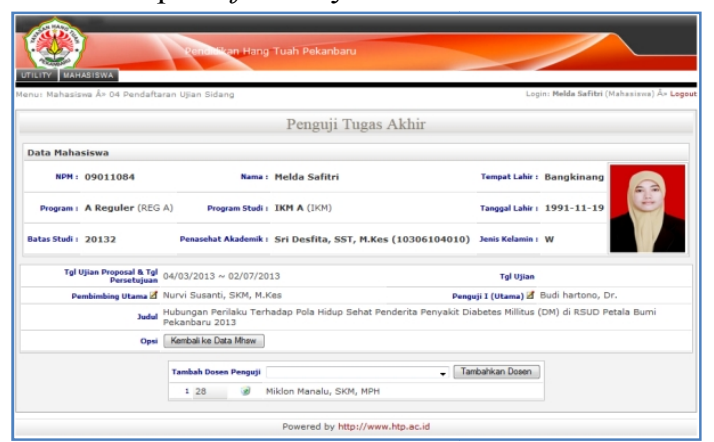

Gambar 14. Form Hasil Tambah Dosen Penguji II

Setelah mahasiswa menambahkan dosen penguji II, klik tombol Kembali ke Data Mhsw untuk melihat kembali tabel

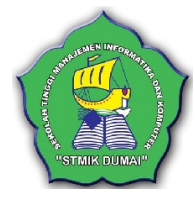

informasi pendaftaran ujian sidang. Kemudian mahasiswa harus menetapkan tanggal ujian sidang dan menginputkan dosen Penguji I (Utama). Berikut form tampilan menetapkan tanggal ujian dan tambah dosen penguji I:

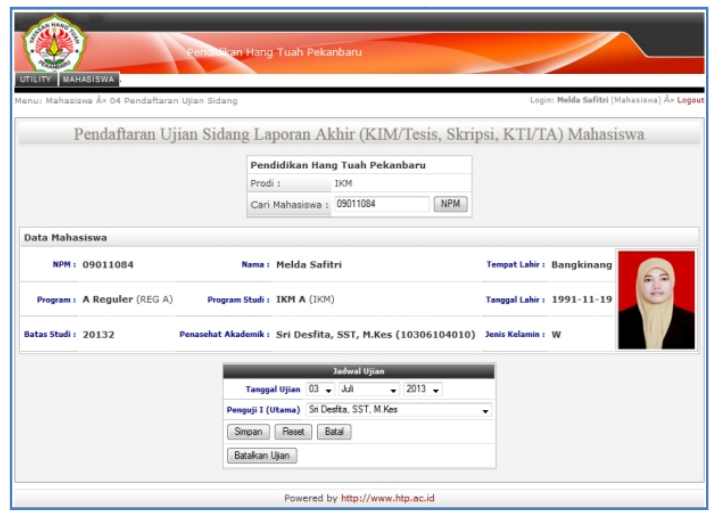

Gambar 15. Form Menetapkan Tanggal Ujian dan Tambah Dosen Penguji I (Utama)

Setelah mahasiswa menetapkan tanggal ujian dan dosen punguji I, klik simpan untuk kembali ke tabel informasi pendaftaran ujian sidang. Langkah berikutnya jika ada mahasiswa yang mempunyai pembimbing pendamping dalam menyusun skripsi, maka untuk menambahkan klik tombol edit yang ada dikolom pembimbing/penguji. Setelah mahasiswa memilih dosen pembimbing pendamping pada listbox Tambah Dosen Pembimbing dan klik Tambahkan Dosen dan hasilnya pada tampilan form berikut:

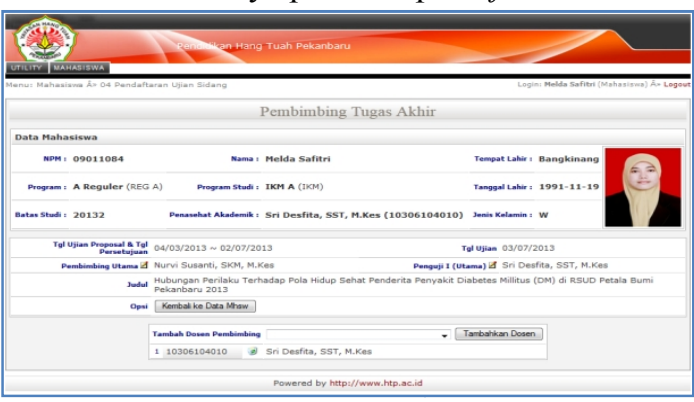

Gambar 16. Form Hasil Menambahkan Dosen Pembimbing Pendamping

Kemudian mahasiswa klik tombol Kembali ke data mahasiawa untuk melihat hasilnya pada tabel informasi pendaftaran ujian sidang. Berikut tampilan akhir form tabel informasi pendaftaran dan tanggal ujian sidang yang telah ditentukan oleh mahasiswa sendiri. 
I N F ORM A I K A

Jurnal Informatika, Manajemen dan Komputer, Vol. 11 No.1, Mei 2019

eISSN : 2580-3042

pISSN : 1979-0694

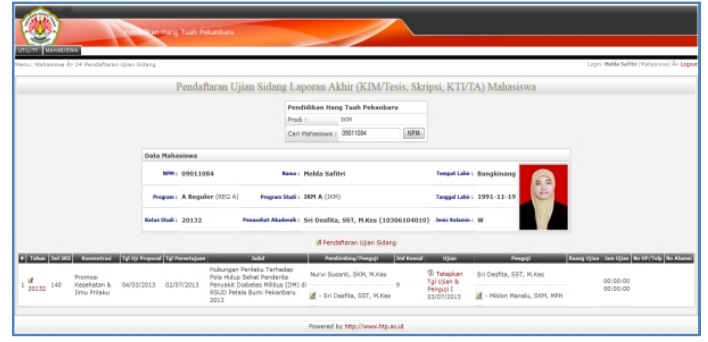

Gambar 17. Form dan Tabel Informasi Pendaftaran Ujian Sidang Setelah Ditetapkan Penguji I, Penguji II dan Tanggal Ujian Oleh Mahasiswa

Untuk perubahan data/edit data mahasiswa, terlebih dahulu mahasiswa konfirmasi ke administrator untuk mengatasi pengguna yang tidak bertanggung jawab dalam merubah data. Adaministrator akan memberikan arahan dalam perubahan data. Perubahan data dapat dilakukan dengan mengklik tulisan tahun pada kolom tahun akan muncul form berikut:

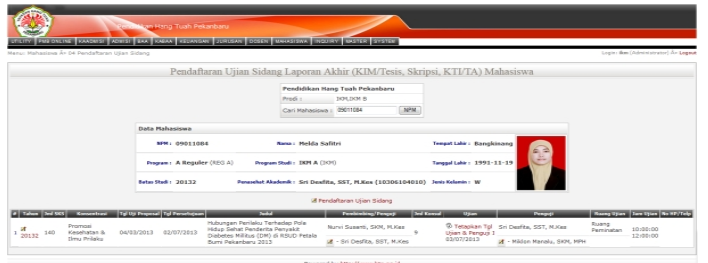

Gambar 18. Form Pesan untuk Perubahan Data Berdasarkan form pesan diatas yang digunakan untuk merubah data, jika mahasiswa ingin merubah data mahasiswa tinggal menggeserkan form tersebut kebawah dan jika mahasiswa langsung mengklik tulisan tahun atau tanpa konfirmasi ke administrator akan tampil form berikut:

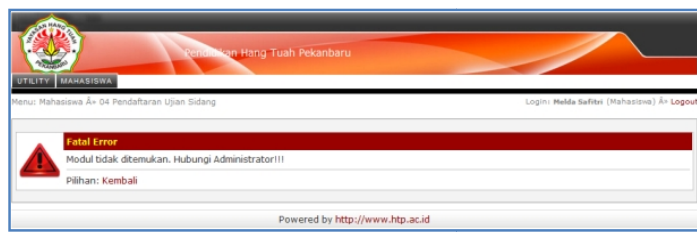

Gambar 19. Form Pesan Fatal Error

Selanjutnya mahasiswa mengkonfirmasi ke bagian panitia laporan akhir bahwa telah mendaftar untuk mendapatkan jam ujian dan ruang ujian. Bagian panitia laporan akhir mengkonfirmasi dengan masuk menggunakan login administrator. Bagian panitia laporan akhir menggunakan kode login prodi masingmasing untuk verifikasi pendaftaran ujian

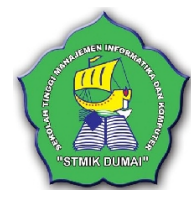

sidang oleh mahasiswa dan aka tampil menu utama administrator Dari form menu administrator bagian panitia laporan akhir bisa membuka memilih menu mahasiswa kemudian sub menu pendaftaran ujian sidang untuk konfirmasi hasil pendaftaran oleh mahasiswa maka akan tampil form tabel informasi pendaftaran. Selanjutnya bagian panitia laporan mengedit untuk menginputkan jam ujian dan ruang ujian dengan mengklik tahun pada kolom tahun, langkah berikutnya untuk menyimpan data dengan mengklik tombol Simpan, dan akan tampil kembali tabel form informasi pendaftaran yang mana jam dan ruang ujian sudah ditentukan, berikut tampilan form-nya:

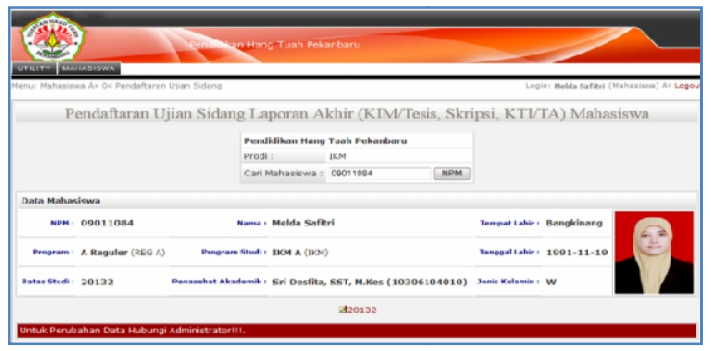

Gambar 20. Form Tabel Informasi Pendaftaran Ujian Sidang yang Verifikasi Adminitrator Bagian Panitia Laporan Akhir

\section{KESIMPULAN}

Berdasarkan hasil penelitian dan pembahasan, maka didapatkan kesimpulan yang dapat diambil dari penelitian ini, bahwa pengembangan Sistem Informasi Akademik untuk Pendaftaran Ujian Sidang Laporan Akhir (KIM/Tesis, Skripsi, KTI/TA) Mahasiswa STIKes Hang Tuah Pekanbaru berhasil dibangun dan kembangkan. Form pendaftaran ujian sidang ini bisa diakses secara online oleh mahasiswa dan sistem mampu mengelola data laporan akhir, menyimpan, merubah, dan membatalkan penginputan data.

Pengembangan Sistem Informasi Akademik STIKes Hang Tuah Pekanbaru dengan penambahan modul pendaftaran ujian sidang memudahkan bagian pihak akademik/panitia laporan akhir dalam dokumentasi form pendaftaran ujian sidang laporan akhir (KIM/Tesis, Skripsi, dan KTI/TA) mahasiswa.

Form pendaftaran ujian sidang ini juga sudah menyediakan tabel form informasi tentang data laporan akhir (KIM/Tesis, Skripsi, dan KTI/TA), informasi tanggal, jam dan ruang ujian bisa diperoleh oleh pimpinan, dosen pembimbing dan penguji laporan akhir serta pengguna (user) lain 
I N F ORM A IK A

Jurnal Informatika, Manajemen dan Komputer, Vol. 11 No.1, Mei 2019

eISSN : 2580-3042

pISSN : 1979-0694

yang mempunyai hak akses terhadap sistem informasi pendaftaran ujian sidang laporan akhir.

\section{REFERENSI}

Aditama, R. (2013). Sistem Informasi Akademik Bebasis WEB dengan PHP. Yogyakarta: Lokomedia.

Agung, H. (2016). Perancangan Database untuk Aplikasi Sistem Kemahasiswaan pada Mobile. Jurnal Teknologi Informasi, V.12 No.1, 15-23.

Anhar. (2010). Panduan Menguasai PHP dan MySQL secara Otodidak. Jakarta: MediaKita.

Ismael. (2017). Rancang Bangun Sistem Informasi Penyaluran Semen Padang untuk Daerah Bengkulu Selatan di CV. Mutia Bersaudara. Jurnal Edik Informatika, V3.i2, 147-156.

https://doi.org/10.22202/jei.2017.v3i2.1569

Kadir, A. (2014). Pengenalan Sistem Informasi (Edisi Revi). Yogyakarta: Andi.

Kadir, A., \& Triwahyuni, T. C. (2013). Pengantar Teknologi Informasi (Edisi Revi). Yogyakarta: Andi.

Sarosa, S. (2017). Metodologi Pengembangan Sistem Informasi. Jakarta: Indeks.

Sukamto, R. A., \& Shalahuddin, M. (2013). Rekayasa Perangkat Lunak Terstruktur dan Berorientasi Objek. Bandung: Informatika. 